\title{
Religión y COVID 19 en el Perú del Bicentenario. Laicidad de colaboración y reacciones evangélicas a la pandemia
}

\section{Paulo Barrera Rivera*}

\section{Resumen}

El Perú ha sido el primer país en América Latina en decretar el confinamiento total frente a la pandemia del COVID-19. Al cabo de tres meses, sin embargo, el impacto del virus ha sido más fuerte que en los países vecinos. Este artículo estudia las reacciones religiosas al confinamiento obligatorio. Toma en cuenta, como preámbulo necesario, las condiciones precarias del sistema de salud pública y la genuflexión del Estado, desde los años noventa, frente a las grandes empresas que lucran con la salud. Se analizan los actos públicos de colaboración emergencial entre Iglesias y Estado, que configuran una "laicidad de colaboración", en plena pandemia. Se propone una tipología de las reacciones del campo evangélico a la pandemia que los obliga a cerrar los templos y reorganizar sus actividades religiosas. Se toman como base empírica las prácticas evangélicas en ambiente virtual, tales como, Facebook, grupos de WhatsApp, entrevistas remotas a líderes y lideresas, programas de radio y tv disponibles en internet. La información fue recogida entre mediados de marzo y mediados de junio del 2020. Las conclusiones apuntan a respuestas religiosas diversas, desde las que entienden la responsabilidad del Estado como garante del derecho a la salud hasta las que niegan que el COVID-19 sea una enfermedad real. En todo caso, frente a las prácticas comunes de "cura divina", la pandemia coloca al desnudo el carácter fundamentalmente secular, médico y clínico, de los cuidados de salud.

Palabras clave: COVID - 19, religión digital, Perú, evangélicos, pandemia

\section{Religião e COVID 19 no Peru do bicentenário. Laicidade de colaboração e reações evangélicas à pandemia.}

\section{Resumo}

O Peru foi o primeiro país da América Latina a decretar o confinamento total frente à pandemia do COVID 19. Mas, logo de três meses, o impacto do vírus tem sido maior que nos países vizinhos. Esse artigo estuda as reações religiosas ao confinamento obrigatório. Levam-se em consideração as condições precárias do sistema público de

* Doutor em Ciências da Religião e professor do Programa de Pós-Graduação em Ciências da Religião da Universidade Metodista de São Paulo. E-mail: dario.rivera@metodista.br 
saúde e a genuflexão do Estado, desde os anos noventa, perante as grandes empresas que lucram com a saúde. Analisam-se os atos públicos de colaboração emergencial entre Igrejas e o Estado, que configuram uma "laicidade de colaboração" em plena pandemia. Propõe-se uma tipologia das reações religiosas do campo evangélico à pandemia que os obrigou a fechar os templos e reorganizar suas atividades religiosas. Tomam-se como base empírica as práticas evangélicas em ambiente virtual, tais como Facebook, grupos de WhatsApp, entrevistas remotas a líderes, programas de rádio e tv disponíveis na internet. A informação foi coletada entre a quinzena de março e a quinzena de junho de 2020. As conclusões apontam uma diversidade de respostas, desde as que entendem ser o Estado garante do direito à saúde até as que negam que o COVID 19 seja uma doença. Em todo caso, perante as práticas comuns de "cura divina", a pandemia coloca ao descoberto o caráter fundamentalmente secular, médico e clínico, dos cuidados da saúde.

Palavras-chave: COVID - 19, religião digital, Peru, evangélicos, pandemia

\title{
Religion and COVID 19 in Peru of the Bicentennial of the Republic. "Laïcité" of Collaboration and Evangelical Reactions to the Pandemic
}

\begin{abstract}
Peru has been the first country in Latin America to decree the lockdown in face of the COVID-19 pandemic. After three months, however, the impact of the virus has been stronger than in neighboring countries. This article studies religious reactions to the lockdown. It takes into account, as a necessary preamble, the precarious conditions of the public health system and the genuflection of the State, since the 1990s, against large companies that profit from health. Public acts of collaboration between Churches and the State are analyzed, which make up a "laicité of collaboration", in the midst of a pandemic. A typology of evangelical reactions to the pandemic that had forced them to close the temples and reorganize their religious activities is proposed. Evangelical practices in a virtual environment, such as Facebook, WhatsApp groups, remote interviews with leaders, radio and TV programs available on the Internet were used as empirical basis. The information has been collected between mid-March and mid-June 2020. The conclusions point to diverse religious responses, from those that understand the responsibility of the State as guarantor of the right to health to those that deny that COVID-19 is a disease. In any case, facing the common practices of "divine cure", the pandemic strips bare the fundamentally secular, medical and clinical character of health care.
\end{abstract}

Keywords: COVID - 19, digital religion, Peru, evangelicals, pandemic

\section{Introducción}

La pandemia del virus, denominado COVID 19, comenzó a manifestar su poder mortal en países asiáticos, especialmente en la China, ya en el mes de diciembre del año 2019. Luego se extendió rápidamente en los países de Europa y América del Norte. En el mes de marzo llegaría a los países de América del Sur entre ellos al Perú, que fue el primero en decretar el Estado 
Religión y COVID 19 en el Perú del Bicentenario. 433 Laicidad de colaboración y reacciones evangélicas a la pandemia

de Emergencia nacional con normas rígidas de confinamiento que obligaron a las iglesias a cerrar sus templos y reorganizar sus actividades religiosas en forma virtual o remota. Es un hecho inédito en varios aspectos, entre ellos, la suspensión de un valor muy caro a las democracias liberales: las libertades individuales y de culto. Este artículo se propone estudiar cómo las iglesias reaccionaron frente a los desafíos y agresiones de la pandemia, fenómeno que no podría ser analizado sin tomar en cuenta al Estado como principal gestor del enfrentamiento nacional a la pandemia. Las prácticas religiosas no se explican apenas por factores internos o teológicos, aunque ellos son muy importantes.

La llegada del COVID 19 al Perú acontece en una coyuntura en que el país se encuentra ya en clima de celebración del bicentenario de vida independiente. De hecho, hay ya desde finales del 2019, un calendario festivo (y no es para menos) pues se trata de celebrar 200 años de vida republicana que se cumplirá en julio del 2021. También, 2021 es año electoral y el virus llega en un momento de preámbulo al inicio de las articulaciones para la campaña correspondiente. En la primera parte de este artículo prestamos atención a las condiciones del sistema de salud que el COVID 19 encuentra a su llegada al país. Esa cuestión no es ajena ni a aspectos estructurales de los ideales republicanos ni a la forma de organizar la relación mercado - Estado en los últimos 30 años. Al contrario, es una cuestión decisiva que determina la pusilánime forma como el Estado organiza el enfrentamiento a la pandemia. En la segunda parte analizamos las articulaciones Estado e Iglesias de cara a la crisis generada por la pandemia. Enfocamos nuestra atención, para tanto, en tres eventos públicos ampliamente divulgados que pueden tipificar una relación emergencial de relaciones de "laicidad de colaboración". Las relaciones Iglesias - Estado, es claro, no se agotan en esos eventos y no es preocupación de este texto analizar propiamente la cuestión de la laicidad. Lo que nos interesa es comprender las articulaciones entre el Estado y los diferentes credos generados por la pandemia y por la crítica situación del sistema de salud que lleva al Estado a apoyarse en todo lo que esté al alcance, inclusive en las religiones.

La tercera parte, que sólo se puede entender en relación con las dos primeras, es probablemente la de mayor osadía o de hecho la más desafiante, se circunscribe al campo propiamente evangélico. Con la intensión de comprender las diversas reacciones evangélicas, ensayamos una tipología de esas reacciones. Proponemos tres tipos ideales de las mismas: a la primera 
la denominamos "Los evangélicos de a pie: con dios y sin el estado". Nos inspiramos para esa denominación en una frase muy utilizada por un pastor pentecostal de una zona popular de Lima que en el "Facebook" (en adelante simplemente "face") se refiere a la gente más pobre como los "ciudadanos de a pie". ${ }^{1}$ A la segunda la denominamos "Evangélicos streaming: Dios y las clínicas están con nosotros". Ese segundo tipo ideal está claramente marcado por las condiciones sociales y económicas ventajosas de iglesias de clase media y media alta que no sufren o sufren mucho menos con la pandemia. Finalmente, el tercer tipo ideal que llamamos "El Evangelio no está en cuarentena: Dios contra el nuevo orden mundial" aglutina a las reacciones religiosas, de diferente condición social y económica, que tienden a negar y actuar pautados en una perspectiva que no reconoce al COVID 19 como una enfermedad real. La expresión "El Evangelio no está en cuarentena" la tomamos del "face" de una iglesia que a riesgo de contagio y desobedeciendo la cuarentena sale a las calles a evangelizar convencidos (así lo manifiestan) de que dios está dando una oportunidad a los pecadores.

\section{Sistema de salud: del "Estado de bienestar" al bienestar de las empresas}

La llegada e impacto rápido del COVID-19 al Perú se ha constituido en un excelente camino para analizar la contradicción entre, por una parte, una saludable economía según los padrones neoliberales y, por otra, la vulnerabilidad social y económica de la mayor parte de la población. Con "vulnerabilidad" nos referimos a la mayor o menor capacidad de reacción frente a riesgos potenciales (KOWARICK 2009). Todas las personas tienen un nivel de vulnerabilidad. Nadie es plenamente invulnerable. La vulnerabilidad en su sentido social y económico es diferente según un conjunto de variables. Más vulnerable frente a riesgos reales o potenciales son, por ejemplo, las personas con menos escolaridad y sus descendientes, porque las desventajas de la baja escolaridad se extienden, en grados diferentes, a la próxima generación. La renta familiar será, más o menos, suficiente o insuficiente según el número de personas que componen la familia y su situación laboral estable o inestable. La posibilidad de enfrentar gastos extraordinarios, extra cotidianos, como los que una situación de emergencia demanda, será menor

Anteriormente ya habíamos encontrado o uso de esa expresión ("Los católicos de a pie") en el estudio de Mallimaci sobre las relaciones entre catolicismo política y Estado, para referirse a los católicos más pobres (MALLIMACI 2013, 97ss). 
en una familia con más personas desempleadas o con salarios menores. El acceso a los servicios de salud, públicos o privados, expresa de forma clara la desigual vulnerabilidad en el Perú contemporáneo. La pandemia que acomete al planeta en el primer semestre de 2020 está demostrando de forma inesperada la enorme desprotección de la mayor parte de la población.

La contradicción, a la que nos referimos al inicio del párrafo anterior, entre economía "saludable" y vulnerabilidad social, se constata en todos los países de América Latina y de forma inversamente proporcional, es decir, cuanto más saludable la economía menos la protección social y económica de su población. En el caso de Perú esa flagrante contradicción, expuesta repentinamente por la pandemia, se muestra particularmente sensible por el clima festivo de conmemoración de los 200 años de vida republicana que el país cumplirá, aún, en julio de 2021 pero cuya agenda de celebraciones ya había comenzado en los últimos meses del 2019. No nos referimos apenas al hecho conmemorativo en sí sino al largo período de vida republicana que desagua en una crítica situación de desprotección social y económica, crisis grave de ciudadanía, de desigualdad. La mayor parte de la población no tiene empleo estable, pues más del 70\% de los trabajadores son informales, ${ }^{2}$ en consecuencia, sin derechos sociales. Como veremos adelante, los servicios básicos de salud tampoco están asegurados para la mayor parte de la población. Al mismo tiempo, la pandemia ha expuesto la gravedad del no acceso a los servicios de saneamiento (agua y desagüe) de importantes parcelas de la población. Los derechos básicos de ciudadanía han quedado expuestos, como los cadáveres de las personas fallecidas que permanecieron arrojados en las calles, por días sin que nadie, especialmente el Estado, les diera "cristiana sepultura" (cabe la expresión en un país mayoritariamente cristiano) sin riesgo de ser contaminado por el COVID 19.

De esos 200 años de vida republicana, los últimos 30 corresponden al establecimiento de una economía neoliberal, que beneficia a las grandes empresas y exige mínima o nula intervención del Estado en la economía. En esa dirección fueron todos los gobiernos desde el primer gobierno de Alberto

\footnotetext{
Según datos del INEI (Instituto Nacional de Estadística e información) recogidos por la Defensoría del Pueblo, en el 2019, 72\% de la población económicamente activa estaba en el sector informal, llegando en algunas regiones hasta el 91\%. Cf. Estado de emergencia sanitária: el problema de la informalidad laboral en una economia confinada". Disponible en: https://www.defensoria.gob.pe/wp-content/uploads/2020/04/Seriede-Informes-Especiales-N\%C2\%B0-02-2020-DP-Problema-de-la-informalidad-laboralen-una-economia-confinada.pdf
} 
Fujimori al inicio de los años noventa. Son 30 años de bonanza económica para las grandes empresas. La pandemia llega también al cabo de 30 años de vida democrática (inestable, sin duda) y desvela violentamente una sociedad profundamente desigual, racista y patriarcal. La misma que así se manifiesta en sus reacciones a la gestión de la pandemia de parte del Estado. En este artículo, nos interesa en específico las cuestiones vinculadas a la salud y a las religiones. Y no se trata, evidentemente, de revisar la cuestión a lo largo de esa historia republicana. Sin embargo, es interesante prestar atención a los orígenes del "seguro social" porque permiten entender el disimulado paso de un régimen de "Estado de bienestar" a otro de "bienestar" pero de las empresas en los últimos 30 años. La cuestión es necesaria también por otro motivo, y es que arroja luz sobre la genuflexión ${ }^{3}$ del Estado "democrático" del actual gobierno del Presidente Martín Vizcarra ante las grandes empresas privadas del sector salud o vinculadas a ese sector, por ejemplo, las empresas productoras de oxígeno medicinal.

Hasta la tercera década del siglo XX el bienestar social en el Perú relacionado a la salud estaba bajo la administración religiosa de la "Beneficencia Pública". Entre el final de los años 30 e inicio de los años 40 comenzaron a madurar lentamente ideas alrededor de la necesidad de una gestión estatal de la salud y de los hospitales. Substituir una gestión caritativa y religiosa por otra científica y médica. Simultáneamente gana fuerza un importante ideal republicano: la salud pública sería un deber del estado para el bienestar de la población (DRINOT 2016, 246). Un sutil, pero muy importante, cambio de sentido se esconde en el paso de la caridad religiosa de la Beneficencia hacia la gestión científica de los hospitales. Junto al Estado, supuestamente soberano, estaban al inicio del siglo XX las grandes empresas (especialmente las mineras) como instituciones importantes para el desarrollo y la modernización del país. Frente a la propuesta de un Seguro Social esas empresas viven el siguiente conflicto. Por un lado, sienten la necesidad de amenizar los riesgos del trabajo porque necesitan de la mano de obra dispuesta. No es por caridad hacia los más pobres. Es para reducir el riesgo de que las agruras del duro trabajo llevasen a los obreros a reacciones políticamente organizadas juntándose a la "violencia de los excluidos":

El Presidente "Se ha bajado los pantalones" ante la empresa privada. Así lo expresa un Pastor pentecostal (en el facebook) que previamente, como buen evangélico, pide disculpas por el uso de la "mala palabra". 
Religión y COVID 19 en el Perú del Bicentenario. 437 Laicidad de colaboración y reacciones evangélicas a la pandemia

Los peones de las grandes plantaciones de la costa, los mineros que, únicamente en el departamento de Cerro de Pasco eran más de 30,000 en la década del 30, comenzaban ya a agruparse en sindicatos. En la región urbana de Lima todos os empleados de transportes, cuyos sindicatos, al parecer, estaban en manos de dirigentes anarco-sindicalistas, habían declarado en 1919 una huelga general. (BOURRICAUD 1967, 106)

Por otro lado, las grandes empresas no quieren participar en los costos del Seguro Social, porque lo consideraban muy altos. La perversidad de las grandes empresas frente a la salud de los obreros es muy clara. Quieren obreros saludables y dispuestos al trabajo duro, lo que inevitablemente tendría implicaciones en su salud, pero no quieren ser copartícipes de los costos de un "Sistema de Salud":

En 1936, percibiendo los altos costos que el Seguro Social y otras nuevas iniciativas legislativa - como la ley de compensación - representaban, muchos de los grandes empleadores, entre ellos la Peruvian Corporation y a la Cerro de Pasco Copper Corporation, así como las cámaras de comercio de las ciudades más importantes estaban preparando protestas para prevenir la promulgación de estas leyes. (DRINOT 2016, 253)

El abogado Rebagliate (cuyo nombre será posteriormente perpetuado en el nombre de uno de los principales hospitales del país), que era el articulador de la propuesta del Seguro Social, tuvo que esforzarse para convencer a los patrones que debían ver su aporte a Seguro Social como una inversión que les permitiría reducir costos, como lo señala Drinot:

El aporte patronal al Seguro Social, era en realidad, una inversión que permitiría a los empleadores reducir costos a través de las ganancias en la productividad de la mano de obra (en línea con la lógica fordista) e incrementar ventas gracias al aumento del poder adquisitivo de la gente. (2016, 261).

Es en ese contexto de cambio de perspectiva del papel de los hospitales, yendo de la caridad religiosa a la fundamentación científica de la salud y de inmediato a las ventajas económicas de un Seguro Social para la inversión capitalista, que se inauguró al final de los años 40 el Hospital del Obrero como la primera gran obra del Seguro Social. En 1948 se inauguraría también el "Seguro Social del Empleado". La caridad religiosa y la filantropía secular pasaron a un segundo plano, siendo substituidos por el papel central 
del Estado como gestor y garantía de esos servicios. Es importante recordarlo en el actual contexto de pandemia en el que el modelo neoliberal obliga al Estado a no intervenir en la economía de mercado.

Líneas arriba decíamos que la pandemia llegó a un país profundamente desigual, patriarcal e racista. El Seguro Social se constituye excluyendo radicalmente a la población indígena, a pesar de su mayoritario peso demográfico. Sin entrar en los detalles de la cuestión cabe subrayar que la principal razón de tal exclusión era de carácter racista. El indio para poder beneficiarse del Seguro debía mostrar que era capaz de ingresar a la vida industrial, debía convertirse en un "trabajador", en un obrero, debía dejar de ser indio. El racismo contra el indio (y luego contra el "cholo") será una constante a lo largo de la República, pero está presente, como es sabido, desde la Colonia. Las luchas anticoloniales, que contaron con su protagonismo, no lo reivindicarán por evidente racismo. Como lo señala con precisión Flores $(1994,216 s s)$ la categoría de indio surge con la conquista "con el propósito de homogeneizar forzosamente a población vencida". Antes de la llegada del europeo en la región andina existían "runas" (hombres) que pertenecían a diversos grupos étnicos. Fueron incorporados al "circuito productivo" como mano de obra en la actividad minera. Fundamental para el enriquecimiento del Nuevo Mundo el indio fue históricamente visto como ser inferior. Por racismo entendemos, afirma Flores:

Algo más que el menosprecio y la marginación: entendemos un discurso ideológico que fundamenta la dominación social teniendo como uno de sus ejes la supuesta existencia de razas y la relación jerárquica entre ellas. El discurso racista en el Perú se estructuró alrededor de la relación blanco-indio y después se propaló a otros grupos sociales. La fuente de este paradigma debemos buscarla en el establecimiento de la dominación colonial. (FLORES 1994, 216)

A principios del mes de abril de 2020, ya en plena pandemia, una carta de la Defensoría del Pueblo dirigida al gobernador del departamento de Loreto muestra la persistencia del racismo. ${ }^{4}$ Se trata en específico de la población indígena amazónica. El siguiente trecho es revelador:

Como es de conocimiento público, Loreto es el segundo departamento a nivel nacional con el mayor número de personas afectadas por el coronavirus,

4 Disponible en: https://www.defensoria.gob.pe/areas tematicas/acceso-a-la-salud/. Acceso: 30/04/2020. 
registrando al día 2 de abril, un total de 72 casos confirmados y el lamentable fallecimiento de dos personas. Evidentemente, estas cifras podrían propiciar que el virus se propague de la ciudad hacia las más de 1,560 comunidades indígenas existentes en dicho departamento, en caso de no adoptarse medidas urgentes y efectivas. (OFICIO No 118-2020-DP/AMASPPI)

Los estudios sociales de género están mostrando, desde las últimas décadas del siglo XX, la persistencia de una visión y gestión patriarcal de la sociedad peruana. Su principal característica es la violencia contra las mujeres, naturalizada en la estructura de la sociedad y en las prácticas cotidianas. Los estudios más recientes muestran la letalidad de esa violencia y el espacio familiar como escenario principal de los feminicidios. La pandemia llega al Perú en una coyuntura de aumento brutal y alarmante de feminicidios, pero cuyo carácter estructural aún precisa ser desvelado:

Un feminicidio no es equivalente al homicidio de una mujer, se trata del asesinato de una mujer por el lugar subordinado que ocupa en la estructura de poder de la sociedad. Esto o tiene correlato en los hombres, ya que no existe una estructura social de poder que los coloque en situación de subordinación con respecto a las mujeres. Sin embargo, para una aproximación, se puede comparar la prevalencia del tipo de feminicidio más común, el íntimo (el asesinato de la mujer en manos de su pareja / expareja), con su contraparte en el caso de los hombres. Si consideramos esas cifras vemos lo flagrantemente más grave y alarmante que es el tema para el caso de las mujeres. Del total de muertes en manos de la pareja, el 78\% de las víctimas fueron mujeres, mientras que el 22\% fueron hombres. (MOTTA 2019, 39)

El confinamiento exigido por la pandemia ha expuesto aún más a las víctimas de la violencia intrafamiliar. En oficio dirigido a la Ministra de la Mujer y Poblaciones Vulnerables, Gloria Montenegro Figueroa, (3 de abril de 2020), la Defensoría del Pueblo argumenta:

Es grato dirigirme a usted para saludarla cordialmente y expresarle nuestra preocupación institucional por la atención de casos de violencia contra las mujeres e integrantes del grupo familiar, en el actual estado de emergencia sanitaria declarado en nuestro país. Como es de su conocimiento, en este contexto, dicha problemática se ve agudizada por el aislamiento social obligatorio ordenado por el Estado. Ello, debido a que muchas de las víctimas se ven obligadas a convivir, de manera ininterrumpida, con sus agresores, provocando que la violencia contra ellas sea silenciosa, sistemática y exponencial. (Oficio No 071-2020/DP. El subrayado es nuestro). ${ }^{5}$

Disponible en: https://www.defensoria.gob.pe/areas tematicas/acceso-a-la-salud/. Acceso: 05/05/2020. 
El mismo mes de abril (día 14) la Defensoría del Pueblo manifiesta similar preocupación en relación a las niñas, niños y adolescentes, en oficio dirigido a la Fiscal de la Nación, Zoraida Ávalos Rivera. En ambos casos se registra el aumento del riesgo al aumentar el tiempo obligatorio de convivencia con el agresor. Para el caso de las mujeres, sin embargo, nótese que la Defensoría del Pueblo se refiere a una violencia "silenciosa, sistemática y exponencial":

Para la Defensoría del Pueblo es de especial preocupación la protección integral y el bienestar de niñas, niños y adolescentes en todos los espacios en los que desarrollan sus vidas, especialmente, en los intrafamiliares. Por ello, desde el inicio de la emergencia sanitaria, nuestra institución instó a reforzar las medidas de atención y servicios ante un posible aumento de casos de violencia durante el periodo de aislamiento social obligatorio. Si bien éste es necesario para contener la propagación del COVID-19, también es evidente que pone en riesgo a las víctimas pues estarían conviviendo con sus agresores/ as. (Oficio No ${ }^{\circ}$ 880-2020/DP. Subrayado nuestro) ${ }^{6}$

Los resultados, recientemente publicados, de la Encuesta Nacional sobre Relaciones Sociales (ENARES 2019) muestra que la preocupación de la Defensoría del Pueblo tiene fundamento en datos comprobados. El porcentaje de mujeres a partir de 18 años de edad que ha sufrido "violencia física y/o psicológica y/o sexual" alguna vez en su vida es de 67.6\%. Dato asustador y revelador, pues, ha cambiado muy poco comparado con los dados de 2015 (68.2\%) y 2013 (72,7\%). Al mismo tiempo, el 22\% han sido víctimas de algún o varios de esos tipos de violencia en los últimos 12 meses. Se trata de un grave problema instalado en la cultura cotidiana, siendo el esposo o compañero el principal agresor (58.8\% en 2019) y las mujeres separadas ("anteriormente unidas") o solteras también lo sufren: $79 \%$ y 48.4\% respectivamente han sido víctimas en los últimos 12 meses.

Tanto la violencia contra mujeres como la violencia contra menores tienen implicaciones importantes con el campo religioso, pues especialmente en la segunda década del siglo XXI se ha configurado un activismo político / religioso contrario a la igualdad de género (BARRERA 2017) con efectos nefastos contra las mujeres por la violencia que incentivan (MOTTA 2019). En la tipología de reacciones al confinamiento, desarrollado en la tercera parte de este artículo volveremos a esa cuestión.

6 Disponible en: https://www.defensoria.gob.pe/areas_tematicas/acceso-a-la-salud/. Acceso: 05/05/2020. 
Religión y COVID 19 en el Perú del Bicentenario. 441 Laicidad de colaboración y reacciones evangélicas a la pandemia

La desprotección de la mayoría de la población frente a la pandemia es concomitante al bienestar de las grandes empresas que lucran desvergonzadamente con las urgencias de las primeras y con consentimiento del Estado. Nos referimos a continuación a dos hechos que lo comprueban. El primero vinculado al chantaje con los precios del oxígeno medicinal. El segundo a la genuflexión del estado frente a los precios abusivos de las grandes empresas privadas de salud, dígase, las clínicas privadas y las redes de farmacias.

Como ha sido ampliamente divulgado en los diversos medios de comunicación, la pandemia aumentó exponencialmente la demanda del oxígeno medicinal. La falta de previsión de parte del Estado queda al descubierto al mismo tiempo que muestra su fragilidad frente a las empresas pues a principios de junio, a casi tres meses del inicio de la cuarentena, el oxígeno medicinal se hizo inaccesible. El diario "Ojo Público" denunció el monopolio (antiguo y de alcance nacional) de la producción de oxígeno en el Perú ${ }^{7}$ y la Defensoría del Pueblo lo denunció en oficio del 6 de junio. El siguiente párrafo lo sintetiza:

Conviene precisar que el mercado de oxígeno en el Perú es altamente concentrado, con solo dos compañías que se reparten la mayoría del mercado productor de oxígeno de alta pureza. Estos agentes son: Linde Praxair que tiene el $82 \%$ al $85 \%$ de producción y Air Products que tiene entre el 15\% y $18 \% 27$. Estas, además son las empresas matrices de los mayores abastecedores de oxígeno medicinal al Estado, según información del Organismo Supervisor de las Contrataciones del Estado (Defensoría del Pueblo, Informes Especiales $\mathrm{N}^{\mathrm{o}}$ 017-2020-DP p.10. El subrayado es nuestro). ${ }^{8}$

El mes de junio también ha sido un mes dramático por la falta de camas del Servicio público y los altísimos precios de las clínicas particulares. Desde mediados del mes de abril el Presidente anunciaba un acuerdo para que los costos de servicios de cuidados intensivos de las clínicas privadas sean cubiertos por dinero público. Sin embargo, dos meses después las clínicas chantajeaban con altísimos precios, al tiempo que la legislación se presentaba ambigua sobre las posibilidades de que el Estado pueda intervenir o exigir el uso de las clínicas en tal situación de pandemia incontenible. Es importante agregar que, desde el inicio de la pandemia, era previsible la insuficiencia de los servicios públicos de

\footnotetext{
https://ojo-publico.com/1842/dos-companias-globales-dominan-negocio-del-oxigeno-enperu. Acceso: 12/06/2020

8 Disponible en: https://www.defensoria.gob.pe/areas_tematicas/acceso-a-la-salud/. Acceso: $15 / 06 / 2020$
} 
cuidados intensivos. Los siguientes datos lo corroboran. En octubre de 2019 el mismo Ministro de Salud admitía que había un déficit de 16,000 médicos. ${ }^{9}$ En noviembre del 2019 el sector de salud hizo varias paralizaciones reclamando aumento de salarios y mejores condiciones de trabajo. ${ }^{10}$ En abril del 2020, a menos de un mes del inicio de la cuarentena fue necesario crear un "Comando humanitario para levantar cadáveres" abandonados en las calles. ${ }^{11}$ Finalmente, el 18 de abril el Ministro de Salud, Víctor Zamora, en una mescla de confesión y de impotencia afirma: "Nuestro sistema de salud tiene 30 años careciendo de muchos aspectos. Para esta epidemia, pese a las carencias, nos hemos unido y juntado todos los recursos que teníamos para enfrentarlos, estamos preparados con lo que tenemos". ${ }^{12}$

\section{El Perú en oración: reacción temprana y "laicidad de colaboración"}

El Perú ha sido el primer país de América Latina en tomar decisiones radicales desde el gobierno central para enfrentar la pandemia. Tomó esas decisiones inclusive antes que algunos países de Europa. El 11 de marzo se decreta la "Emergencia sanitaria" y 4 días después (15 de marzo) el estado de "Emergencia nacional" que obliga al confinamiento total y la consecuente prohibición de todo tipo de actividades grupales. Las iglesias deben entonces interrumpir sus actividades y cerrar los templos. Los anuncios de esas medidas fueron minuciosamente explicados por el Presidente en cadena nacional de comunicación en todos los medios. En esa comunicación directa del Ejecutivo con la sociedad en general, y en sucesivas veces entre los meses de marzo a junio, el Presidente usó una eficaz estrategia de compensación (discursiva) tranquilizante y contrastando con la evidente crisis y fragilidad del Sistema de Salud, como demostramos en la primera parte de este artículo. Caracterizan sus mensajes un llamado a la unidad, el patriotismo y el coraje. Al mismo tiempo finge tener las cosas sobre control, especialmente de los recursos sanitarios.

\footnotetext{
9 https://larepublica.pe/sociedad/2019/10/05/ministerio-de-salud-ministra-zulema-tomashacen-falta-mas-de-16-mil-medicos-especialistas-hospital/

10 https://larepublica.pe/sociedad/2019/11/21/medicos-exigen-mejoras-laborales-y-maspresupuesto-lrnd/

11 https://larepublica.pe/sociedad/2020/04/11/coronavirus-en-peru-minsa-victor-zamoraanuncia-la-creacion-de-comando-humanitario-para-levantamiento-de-cadaveres/

12 https://larepublica.pe/sociedad/2020/04/18/coronavirus-en-peru-zamora-sobre-colapsoen-hospital-almenara-por-covid-19-servicios-tienen-que-adecuarse-al-aumento-de-lademanda/
} 
Ejemplo claro es el anuncio de que las clínicas estarían dispuestas para atender a los afectados. El mensaje presidencial permanece en ese horizonte que favorece a las grandes empresas que, deshumanamente, se benefician con la pandemia. Sólo será interrumpido, y desenmascarado, con el aumento de las víctimas, con los escándalos del monopolio del oxígeno medicinal y la actitud mafiosa de las clínicas dispuestas a lucrar al máximo con la pandemia. En esa estrategia no se dejó de lado a los actores religiosos, como veremos a continuación.

Tres importantes hechos se destacan en las relaciones entre las iglesias y el estado en el contexto de la pandemia. Acontecieron en los meses de abril, de mayo y al inicio de junio. Las mismas deben ser entendidas en el marco de una relación cordial, "laicidad de colaboración" (BAUBÉROT et MILOT 2011 y MILOT 2008), que antecede a la pandemia y remite a la caída del gobierno de Alberto Fujimori. Los autores que acabamos de mencionar proponen hasta seis tipos de laicidad, entre ellos la "laicidad de colaboración" que tiene las siguientes características. A pesar de los procesos de laicidad consolidados en los países de Europa, las democracias consolidadas han mantenido modelos de cooperación con las iglesias, asociaciones de caridad o de ayuda internacional. El Estado, en esos casos, mantiene firme voluntad de colaboración con las instituciones religiosas lo que genera interlocutores privilegiados. ${ }^{13}$ Sería el caso de la Iglesia Católica en el Perú. Nos parece necesario dos ajustes en el modelo propuesto. La primera es que Baubérot y Milot lo piensan para democracias consolidadas (supongamos que la idea se aplica para Europa). Del Perú, de manera diferente, se puede decir que los períodos democráticos han sido paréntesis en una larga historia autoritaria (FLORES 1999). Por otro lado, en los últimos treinta años, la iniquidad del modelo económico neoliberal ha torpedeado constantemente las bases de construcción de la igualdad ciudadana y, por su parte, las élites políticas (el fujimorismo, el aprismo y la derecha política en general) han fragilizado fuertemente las instituciones del Estado y controlado el poder Legislativo e incluso el poder Judicial en beneficio de las grandes empresas. No tenemos, pues, en el Perú una democracia estable. Al contrario, es una

13 Mallimaci(2015, 230ss) propone otro modelo, "laicidad de subsidiariedad" en el que destaca un aspecto muy importante. En la implementación de políticas públicas y la interpelación al ciudadano el Estado se vale de la intermediación de actores colectivos, entre ellos los religiosos, con ventajas evidentes para la IC cuya "Doctrina social" no sólo coincide con esa perspectiva sino que espera que el Estado no intervenga en asuntos que serían atribución propia de la Iglesia. De forma semejante a las empresas privadas que quieren al Estado a su lado pero no quiere que intervenga en la ecomía. 
democracia muy frágil. En los últimos 30 años el Perú no registra un solo jefe de Estado que no haya tenido problemas con la justicia, especialmente por corrupción. Uno ha sido condenado por crímenes gravísimos (Alberto Fujimori), su sucesor es un fugitivo de la justicia (Alejandro Toledo), otro prefirió quitarse la vida antes de ser procesado (Alan García), otro enfrenta procesos judiciales por corrupción (Ollanta Humala), el ganador en las últimas elecciones de 2016 (Pedro Kuczynski) fue destituido por el Congreso y el actual (que lo ha substituido) ha tenido que intervenir el Congreso Legislativo controlado por partidos que intentaban el retorno del fujimorismo. No se puede decir, pues, que en el Perú tenemos una democracia consolidada o estable. De todas maneras, hecha esas salvedades, el modelo de "laicidad de colaboración" es útil para pensar las relaciones cordiales entra las Iglesias y el Estado en el contexto de la pandemia. La colaboración es fruto de la urgencia del momento y el Estado muestra claramente que necesita la ayuda de las iglesias. Si extendemos la idea al período que se inicia con la caída del régimen fujimorista al inicio del presente siglo, se constatará también una colaboración Iglesias - Estado que surge de una experiencia traumática.

El trauma del desastre del gobierno de Alberto Fujimori dio lugar al surgimiento de un foro de diálogo y acción que se denominó "Acuerdo Nacional" (AN) del mismo que participan desde su inicio las principales iglesias cristianas. La Iglesia Católica (IC) y el Concilio Nacional Evangélico (CONEP) siempre han tenido (desde entonces) asiento en las reuniones y acciones del AN. Flores Galindo, historiador que ya citamos en este texto, afirmaba que a mediados del siglo XIX la IC "había perdido poder tanto sobre los cuerpos como sobre las almas", pues la sociedad tendía a ser cada vez más profana en su ordenamiento político (FLORES 1999, 40). Acto seguido afirma que la República, que a la IC le resultaba adversa, se "edificaba a espaldas del campesino", marginando a la mayoría analfabeta $(2019,40)$. El mismo Flores nos recuerda que los analfabetos sólo tendrán acceso al voto electoral $(2019,32)$, tan caro a las democracias, en el año 1980 (i!). La longeva República, la Democracia y la ampliación de los derechos políticos implicaban una nueva soberanía, la política, la del Estado. Sin embargo, la IC encontró nuevos y muy importantes espacios de acción en una sociedad fuertemente golpeada por el inicuo modelo de economía neoliberal. En pleno siglo XXI la IC mantiene singular relación con el Estado inclusive con privilegios económicos y una amplia red de asistencia social, que aquí no estudiamos. ${ }^{14}$

14 sobre los proyectos sociales de la Ic en el Perú véase Lecaros (2018), especialmente la segunda parte. 
El CONEP, por su parte, representa al más importante sector del campo evangélico desde su fundación al final de los años 40. El grueso del "campo evangélico" (para usar una categoría suficientemente amplia) está representado en el CONEP. Desde los años 80 el CONEP desarrolló una importante articulación en defensa de los derechos humanos (LÓPEZ y ARROYO 2008, LÓPEZ 1998) y a partir de los 90 una actitud crítica de las políticas del Estado (LÓPEZ 2004). Otra institución que surge, más recientemente, para disputar terreno al CONEP y como desconfianza de un ecumenismo latente en el mismo es UNICEP (Unión Nacional de Iglesias Cristianas Evangélicas del Perú). Esa información es suficiente para entender quiénes son los protagonistas que interactúan con el Estado durante la pandemia en esos tres momentos. ${ }^{15}$

El primer hecho a destacar es la oración virtual interreligiosa que aconteció el 7 de abril, a menos de un mes del inicio de la cuarentena. El evento fue iniciativa del "Consejo Interreligioso del Perú - Religiones por la Paz” (CIPRP). Representantes de las más diversas religiones del país participaron. Se gravó un video con las oraciones de los participantes a los que se les asignó un tema específico para orar. El video, de aproximadamente 16 minutos, es de muy buena calidad en imágenes, secuencias y audio. El video tiene el título de "Oración por el Perú y el mundo". Luego de una introducción, de parte de la Secretaria Ejecutiva del CIPRP, cada participante hace una oración. Cada tema de oración es acompañado por imágenes apropiadas y con una música de fondo. En la introducción se declara:

Queremos aportar para un país más justo, más humano y humanizador. Nos unen dos principios, el cuidado del otro y el cuidado de la naturaleza, regalo de Dios para todos nosotros. La grave crisis que estamos viviendo por causa de la pandemia nos recuerda a todos que estamos conectados. Lo que afecta a una persona afecta a todos los demás. Por eso no hay soluciones individuales, todos juntos debemos unirnos para responder desde el cuidado y la unidad. ${ }^{16}$

Luego de la introducción intervinieron representantes de: la CEP (Conferencia Episcopal Peruana), la Iglesia Adventista del Séptimo Día, la

15 Fuera del CONEP y de UNICEP hay un grupo no despreciable de iglesias pentecostales y evangélicas conservadoras en cuestiones políticas que se caracterizan por claro antiecumenismo y ya, en el presente siglo, actúan haciendo causa común en acciones contra toda iniciativa de igualdad de género.

16 Video disponible en: https://noticias-pe.laiglesiadejesucristo.org/articulo/presidentevizcarra-presentar\%C3\%A1-video-de-oraci $\%$ C $3 \% \mathrm{~B} 3$ n-interreligiosa 
Iglesia Ortodoxa Griega, el CONEP, Comunidad Bahais del Perú, Asociación Judía del Perú, Brahma Kumaris del Perú, UNICEP, Asociación Islámica del Perú e Iglesia Jesucristo de los Santos de los Últimos Días. El Video termina con imágenes de la región andina con destaque a Macchu Picchu. Los temas por los que se oraba fueron: médicos, enfermeros y personal de salud, personas que han perdido familiares, por ancianos y vulnerables, trabajadores de limpieza y abastecimiento de servicios básicos, cuerpo de bomberos y voluntarios, personal policial y militar, líderes del gobierno, los que están lejos de sus hogares, por salvación de la pandemia y por la paz y reconciliación de todos.

Además de la excelente producción, en términos tecnológicos, el video tuvo una gran divulgación. Fue anunciado y presentado, de forma emocionada, por el Presidente de la República al final de su pronunciamiento (el mismo día 7 de abril) en red nacional de radio y tv. Luego fue retransmitido innumerables veces en las "redes sociales". Aunque es difícil dimensionar su impacto si es posible afirmar que llegó a la mayor parte de la población que seguía con expectativa las noticias del avance del COVID-19. El hecho, compuesto por el video y su divulgación, fueron un poderoso llamado a la unidad y a la solidaridad. Es evidente una gran afinidad con los mensajes del Presidente y también debe haber contribuido a camuflar la fragilidad en que se encontraba el sistema de salud. De todas maneras, no se debe despreciar el aspecto emocional y psicológico en la conservación de la salud.

El segundo hecho a destacar aconteció poco más de un mes después (14 de mayo). Se trata de un encuentro interreligioso presencial realizado en la Plaza de Armas de Lima, y fue llamada de "Religiones unidas por la salud"17. También fue por iniciativa del CIPRP y esta vez en coorganización con el Ministerio de Salud. Fue un evento minuciosamente organizado y con todos los cuidados de distanciamiento exigidos. Como fue un acto presencial, realizado en pleno confinamiento, su impacto hubiera sido reducido a no ser por la sofisticada tecnología de transmisión en directo utilizada. El evento fue anunciado varios días antes por los principales medios de comunicación y transmitido en cadena nacional por el canal oficial del Estado. Además de todas las religiones que participaron en el video, anteriormente analizado, esta vez también estuvieron presentes: la Iglesia Luterana, la Iglesia Metodista y la Iglesia Anglicada. En representación de la IC esta vez participó el

17 Disponible en: https://www.arzobispadodelima.org/2020/05/14/peru-lideres-religiososunidos-salud/ 
Religión y COVID 19 en el Perú del Bicentenario. 447 Laicidad de colaboración y reacciones evangélicas a la pandemia

Arzobispo de Lima, Mons. Carlos Castillo. Es importante subrayar que el nombramiento de Castillo como nuevo Arzobispo de Lima, en substitución de Mons. Cipriani, representa un importante cambio en el escenario religioso católico. Con la jubilación de Cipriani se cierra un ciclo de hegemonía del Opus Dei en el Perú. El Papa Francisco lo substituyó, por un religioso de clara orientación progresista. Diferente de éste, Cipriani fue importante sustento religioso del fujimorismo y articulador del movimiento religioso "Con Mis Hijos no te Metas". Es muy difícil imaginar que Cipriani hubiera participado de un evento como el que analizamos.

Volviendo al evento en la Plaza de Armas, en la transmisión se intercalaban palabras de representantes religiosos y testimonios de personas que sobrevivieron al virus o que habían perdido familiares. También hubo música en el lugar de los hechos y otras intercaladas en la transmisión. El lugar del evento fue, así, simultáneamente presencial y virtual. La fachada de la catedral servía de un segundo plano en la que se proyectaban imágenes o frases escogidas. De ellas destacamos la siguiente: "Mientras haya vida daremos batalla". Se hizo un minuto de silencio por las víctimas, se depositó una ofrenda floral, se leyó un documento firmado de compromiso de unidad religiosa y lucha por la paz, todos los presentes en la Plaza de Armas estaban uniformados usando máscaras del mismo color gris con una banderita del Perú en un costado de la máscara y el acto concluyó con el Himno Nacional.

Podemos considerar que el hecho cumplió, con mayor impacto, los mismos objetivos del anterior. Esta vez fue muy evidente la interacción iglesias - Estado. Fue un tiempo de consuelo, de unidad religiosa y al mismo tiempo de manifestación de patriotismo. En síntesis, se proyectaba la idea de estar frente a un enemigo común: la pandemia. Menos de un mes después, el Presidente del Consejo de Ministros convocaría a una reunión con las diferentes religiones. Es el tercer hecho que a continuación analizamos.

La nota de prensa del gobierno se refiere a esa reunión, acontecida el día 8 de junio, como el inicio de una nueva etapa llamada "Hacia una nueva convivencia". Además del Presidente del Consejo de Ministros (PCM), Vicente Zeballos, participaron otros 3 ministerios del Estado: la Ministra de la Mujer y Poblaciones Vulnerables, Gloria Montenegro, el ministro de Justicia y Derechos Humanos, Fernando Castañeda y la ministra de Inclusión Social, Ariela Luna. La participación de cuatro Ministros/as confiere a la reunión una dimensión muy importante de la relación del Estado con las iglesias / 
religiones. Participaron "26 entidades religiosas". El PCM reiteró que "la actual circunstancia que vive el país requiere del compromiso de todos". La intensión de la reunión se sintetiza en las siguientes palabras del PCM: "Como Gobierno queremos articular con todos los sectores, entre ellos, con todas las Iglesias, para que nos puedan ayudar a llegar a los ciudadanos que se encuentran en situación de pobreza y extrema pobreza".

A tres meses de inicio de la pandemia el gobierno solicita el auxilio de las instituciones religiosas. Sin poder dimensionar el potencial de acción que las iglesias tendrían, el gobierno presupone una "sensibilidad social de las iglesias" y las invita a "trabajar de forma articulada con el Estado para proteger a la población del impacto del Covid-19". Al mismo tiempo invoca a los "representantes de las iglesias a unir esfuerzos en la protección de los adultos mayores, las comunidades nativas y campesinas, y en la reapertura de los comedores populares".

\section{Tipología de las reacciones en el campo evangélico al confinamiento}

Es importante subrayar que la tipología que aquí proponemos se refiere a la coyuntura específica determinada por la pandemia. Se trata de un ensayo de caracterización de cómo ha sido la reacción del campo evangélico en general al confinamiento y a los efectos del virus. Elaboramos tres tipos ideales en los que caben (digámoslo así) la más diversas prácticas religiosas que se reconfiguraron en los tres meses siguientes al inicio del confinamiento. No se trata, entonces, de una tipología de los evangélicos sin más. Es una tipología marcada por la coyuntura. Sin embargo, como el lector podrá leer y juzgar, los tipos de reacción reflejan significativamente el lugar tradicional de las iglesias evangélicas en la sociedad peruana.

En la elaboración de esta tipología tomamos en cuenta, como no podría ser diferente, las condiciones sociales y económicas del país. El Perú es un país profundamente excluyente. En las palabras de Lecaros:

Para comprende el fenómeno del evangelismo en Lima es necesario tener en cuentan particularmente los fenómenos de la pobreza y la exclusión con detenimiento. Si bien las comparaciones pueden ser complicadas aplicadas a este terreno, el Perú puede ser considerado como el país latinoamericano donde el fenómeno de la exclusión se siente más marcado: una pequeña minoría de blancos (o "blanqueados" al hacer fortuna) marginaliza a la inmensa mayoría, sobre todo a los de origen indígena. (LECAROS 2016,55). 
Hay que decir, aunque parezca desnecesario, que esta propuesta "adolece" de cualquier interés de ser exhaustiva. Precisamente, el método de los "tipos ideales" se propone driblar esa tarea imposible de enfrentar la multiplicidad de casos, aunque debe resultar de la observación amplia de los mismos. ${ }^{18}$ Como lo destacaba el propio Weber, los tipos ideales no son simple producto de la imaginación del investigador (WEBER 1984, 9ss). Está marcada también por los límites de la presencia de las iglesias en las redes sociales mediáticas. Recuérdese que la desigualdad en el Perú incluye también la desigualdad de acceso a la banda ancha (MANRIQUE 2016), aún privilegio de pocos, que, como veremos, no deja de tener impacto en la práctica religiosa durante la pandemia.

\section{A) Los "evangélicos de a pie": con Dios y sin el Estado}

Consideramos aquí a las iglesias, en su mayoría pequeñas o medianas (a juzgar por el número de personas que asisten a las actividades en las redes), de tradición evangélica y evangélica pentecostal. Están presentes en zonas muy populares, de pobreza y extrema pobreza. En muchos casos las personas en esos barrios han salido a buscar trabajar prematuramente, obligados por la crisis económica, exponiéndose al contagio y propagando el virus en los vecindarios. Esas iglesias están en las regiones más populares de la ciudad, como San Juan de Lurigancho, Villa María del Triunfo, San Martín de Porras y Comas. Se sabe que los mercados de esas zonas han sido focos de alto número de contagios. La reacción del Estado se manifestó tardíamente y de forma punitiva. Se clausuraron los mercados, con lo que los vendedores quebraron rápidamente y fuero pocos los que llegaron a recibir los bonos asistenciales del Estada. La razón principal fue que la mayoría de esas personas no tiene una cuenta bancaria. La urgencia por recibir los bonos ofrecidos por el Estado generó largas colas y tumultos en las puertas de los bancos, lo cual fue bastante criticado en las páginas del "face" de esas iglesias o en los cultos en grupos de "whatsapp".

Las condiciones económicas de sus seguidores se detectan en las reuniones de oración, en los estudios bíblicos y en los sermones. En las

\footnotetext{
18 "Obtém-se um tipo ideal mediante a acentuação unilateral de um ou de vários pontos de vista, e mediante o encadeamento de grande quantidade de fenômenos isoladamente dados, difusos e discretos, que se podem dar em maior ou menor número ou mesmo faltar por completo, e que se ordenam segundo os pontos de vista unilateralmente acentuados, a fim de se formar um quadro homogêneo de pensamento". (WEBER 1967, 50).
} 
oraciones son frecuentes los problemas de salud y económicos. Se ora por enfermos de la iglesia que están en cuarentena u hospitalizados, se pide protección por hermanos que necesitarán volver a trabajar ("Que Dios los proteja en el transporte público"). Los líderes exhortan a "ayudar al prójimo que tiene menos pan que nosotros". Los pastores de esas iglesias dependen económicamente del salario que reciben de la iglesia. Se ora por los pastores cuyos salarios han disminuido. Hay que destacar la clara conciencia de los graves riesgos de la exposición al virus y también de la situación económica crítica generada por la pandemia. Pero también, como la mayor parte de la población no esperaban una cuarentena tan prolongada. El 16 de marzo, uno de ellos comunica a la congregación en el Facebook: "por dos semanas seré un Pastor virtual". La necesidad de la comunicación remota les toma de sorpresa y padecen para adaptarse. Hasta mediados de mayo las actividades religiosas se redujeron a estudios bíblicos transmitidos por el "face", sin cualquier interacción inmediata. Sólo cuando descubren que el aplicativo "Zoom" estaba liberado para uso gratuito pasan a reencontrase, verse con la congregación, reflexionan sobre su papel en el mundo virtual y las reuniones de oración ganan interacción. Desde un principio se acata "como buenos ciudadanos" disciplinadamente la cuarentena y se brinda información sobre los cuidados y precauciones. En sus mensajes virtuales se divulga el "QUÉDATE EN CASA".

Tienen consciencia de aspectos estructurales de la situación del país, como a desigualdad de género y la economía neoliberal al servicio de las grandes empresas. Sobre la primera cuestión, así se expresa en un "post" el pastor de una iglesia pentecostal una semana antes ( 5 de marzo) del inicio da cuarentena:

En el frente interno, los ciudadanos de confesión evangélica tienen que preguntarse, ¿existen realmente bases bíblicas y fundamentos teológicos sólidos para oponerse al enfoque de género en las políticas públicas? ¿No es necesario y urgente que en las instituciones educativas se enseñe que hombres y mujeres tienen igual valor, dignidad y derechos? ¿No es necesario y urgente que en las dependencias policiales se atienda como corresponde a las mujeres que solicitan garantías para su vida, denuncian acciones de violencia y piden celeridad en la atención a su solicitud porque peligra su integridad física y su vida? (LOPEZ, post en Facebook del 5 de marzo 2020)

Ya en abril, cuando la pandemia colocaba al desnudo la mezquindad de las grandes empresas, el mismo afirma por ocasión de la Semana Santa: 
Religión y COVID 19 en el Perú del Bicentenario. 451 Laicidad de colaboración y reacciones evangélicas a la pandemia

En este día en que los cristianos afirmamos y celebramos el triunfo de la Vida sobre la muerte, indigna y enoja que en circunstancias tan difícil p ara e país y para el mundo, sectores como La Confederación Nacional de Instituciones Empresariales Privadas (CONFIEP), haya solicitado en días pasados al gobierno (Ministerio de Trabajo) que se les autorice el cese colectivo (despido masivo) de trabajadores. (Ibid, 12 de abril)

Presidente Vizcarra no está bien, nada bien, que Usted y su gobierno hayan cedido a la presión de los grandes empresarios de la CONFIEP...Es lamentable que por su actitud timorata frente a los grandes empresarios, el pueblo de a pie, los millones de pobres, tengan que pagar todo el costo de la crisis, provocada por la pandemia. Los despidos masivos sólo traerán hambre y angustia a quienes ya están sufriendo y no tienen el pan que otros sí tienen de sobra (Ibid, 13 de abril).

Durante varios momentos de los tres meses (aquí estudiados) esas iglesias expresan clara comprensión de la mezquindad del sistema privado de salud: "A las clínicas privadas poco o nada les importa el prójimo...no ven a seres humanos sino a clientes a quienes se les asalta ...la pandemia es para ellas una excelente oportunidad de incrementar sus cuentas bancarias" (Ibid 13 de junio).

Algunas iglesias de este tipo consiguen organizar de forma bien articulada una reacción a la crítica situación. Con varios muertos y muchos contaminados, en la iglesia y en el barrio, se decide constituir la Comisión "Iglesia y Salud: organizados contra el Covid y la usura". Las acciones incluyen recolección de víveres y distribución de canastas básicas para familias de la Iglesia y allegados (1 vez al mes), apoyo espiritual con oraciones personalizadas mediante celular para apoyo emocional, talleres sobre alimentación saludable, medicina alternativa y salud mental. Todas esas actividades deben ser valoradas en la crítica situación de abandono de parte de Estado, pues el hospital más cercano ya se encontraba colapsado en el mes de mayo. Recién al inicio de junio comienza a llegar recursos del Estado que contribuyen a las actividades de un comedor popular que la iglesia ya administraba. Otras dos actividades muy importantes ante el impacto de la grave crisis sanitaria son los cultos de testimonios y de consuelo a los familiares de fieles que murieron víctimas del COVID 19 y fueron cremados, sin tener velorio ni entierro. Diferente del tipo tres, que veremos más adelante, se manifiesta clara consciencia del peligro del virus y no se ocultan los efectos dolorosos de las pérdidas. Además de los cultos de consuelo se 
busca apoyo psicológico para asistir a los afectados. Todas esas actividades fueron organizadas a través de grupos de "whatsapp". La otra acción, que muestra clara consciencia del largo alcance en el tiempo que la pandemia tendrá en el país, en razón del aumento sostenido del número de contagiados y la ineficacia del estado a los más vulnerables, es la promoción y apoyo de pequeños negocios que varias familias ya tienen como venta de artesanía, de tejidos, alimentos caseros, útiles de limpieza, etc. El objetivo es movilizar una economía familiar de sobrevivencia para los próximos meses.

Las iglesias más pobres, de este primer tipo, acataron la cuarentena de inmediato y sus miembros dejaron de trabajar, a pesar de sus condiciones económicas precarias. Suspendieron los cultos y luego de algunas semanas comenzaron a realizar cultos en el grupo de whatsapp que ya existía para comunicación interna. No pocas carecen de condiciones para usar otra plataforma digital, inclusive las gratuitas porque la mayor parte usa celulares cuya memoria no las soporta. En estas iglesias pocas personas tienen computador en casa, de manera que los cultos virtuales sufren con la mala calidad de imagen y sonido. El alcance de su transmisión está limitado al grupo. Sin embargo, la solidaridad ha estado muy presente desde las primeras semanas de la cuarentena. Se distribuye canastas básicas sólo entre los miembros más afectados por la economía en paralización. Los costos son cubiertos por las familias que consiguieron seguir trabajando desde casa. Al paso de la cuarentena la situación económica se hizo más crítica llevando a diversas iniciativas económicas informales, como venta de "kekes" y empanadas entregadas a domicilio.

Como ejemplos de este primer tipo encontramos a la Iglesia de Dios del Perú de Villa Maria del Triunfo en el Cono Sur de Lima y a la Iglesia Evangélica Peruana de Comas en el Cono Noreste de la ciudad.

\section{B) Evangélicos "streaming"19: Dios y las clínicas están con nosotros}

Clasificamos en este tipo a las iglesias de mejores condiciones económicas. Están situadas en regiones privilegiadas de la ciudad, como

19 El término "stream" en inglés significa flujo, corriente, riachuelo. Existe el verbo correspondiente "to stream" sinónimo de "to flow". En el contexto contemporáneo de divulgación de información amplia y rápida, de imágenes, áudio y vídeo, por la internet el sustantivo "streaming" adquirió la siguiente definición: "the activity of listening to or watching sound or video directly from the internet". Cf. https://dictionary.cambridge. $\mathrm{org} / \mathrm{pt} /$ dicionario/ingles-espanhol/streaming 
Religión y COVID 19 en el Perú del Bicentenario. 453 Laicidad de colaboración y reacciones evangélicas a la pandemia

Surco, Monterrico, La Molina y Miraflores. Todos, distritos de clase media y media alta. Todas acataron de inmediato la cuarentena y en la misma semana informaban, en culto especial por internet que "la cuarentena es bíblica". El cierre de los templos no les afecta. Al contrario, parece haber facilitado la interacción virtual entre sus fieles. La posibilidad del contagio con el virus no aparece, lo que muestra una seguridad privilegiada a lo largo de los tres meses. Hay que recordar que las clínicas privadas permanecieron inclementes a las urgentes demandas de camas y de atención general hasta bien avanzado el mes de junio. La crisis económica tampoco aparece como un problema.

A partir de las semanas siguientes al inicio de la cuarentena realizaban todas sus actividades religiosas de forma remota: estudios bíblicos, reuniones de oración, sermones, diálogos informales y amenos. Todas están registradas en su página del Facebook o en múltiples redes. Los videos de sus actividades religiosas muestran las siguientes características. Las transmisiones son de alta calidad en audio e imagen. Hacen uso sofisticado de imágenes y textos que dan soporte y refuerzan el mensaje transmitido. No son personas que pasan dificultades económicas, lo cual se percibe claramente en las reuniones de oración. Se ora por los otros, los que pasan hambre, los que están sin trabajo, los que tienen que usar el transporte público. Sus seguidores están en el polo opuesto de los "evangélicos de a pie", de nuestro primer tipo. En todos los cultos se expone también las cuentas bancarias para los diezmos y ofrendas. Comparadas las reuniones de oración de junio con las de abril se percibe una novedad: de orar por las autoridades se va hacia quejas contra el presidente y la corrupción. No se encuentra, sin embargo, ninguna crítica a la gestión de la pandemia y menos as sistema económico. De todas maneras, como ya fue abordado en la primera parte de este artículo, la gestión de la pandemia favoreció al sector empresarial, al que evidentemente los fieles de este tipo de iglesia tienen vinculada su economía.

Una iglesia, situada en La Molina”, uno de los distritos más privilegiados de la ciudad de Lima, comenzó sus actividades virtuales días antes del inicio de la cuarentena obligatoria. Inclusive se adelantaron. En la semana del 9 al 14 de marzo (2020) ya estaban tomando precauciones (puntos de alcohol en gel en diversos lugares del templo y "mucho jabón en los baños", como se anunciaba desde el púlpito) y en esa misma semana comienzan sus cultos vía internet. Los discursos del Pastor al inicio de la cuarentena muestran que tiene información previa de las decisiones que el Gobierno tomaría. Eso se explica por las relaciones cercanas de sus líderes 
con las élites políticas, especialmente del APRA y del fujimorismo. Una importante líder del APRA, Mercedes Cabanillas, ha sido miembro de esa iglesia. El argumento para cerrar el templo y someterse a la cuarentena puede sintetizarse en la siguiente frase tomada de uno de los sermones: "Dios es nuestro protector, pero necesitamos mucha prudencia. Dios nos está probando". Los videos y mensajes en su "face" no muestran ningún reclamo por el cierre del templo. Los recursos técnicos de audio y video son sofisticados. Los "cultos de oración vespertinos" no revelan ningún problema de salud entre los miembros. Se ora por las autoridades, se critica la corrupción, se clama por protección divina a "esta gran nación".

Otra iglesia, situada en el privilegiado distrito de Monterrico, se destaca por su. altísima performance en internet. Es la iglesia "streaming". Los "ríos de agua viva" corren por múltiples redes, todas con excelente calidad. A lo largo de la cuarentena desarrollan actividades religiosas, de alta interactividad, casi todos los días y varias veces al día. Antes de la cuarentena ya transmitían sus cultos en múltiples redes. Parte importante de los muchos "lives" expone sus actividades de distribución de productos básicos e inclusive de dinero entre población pobre de regiones populares. En la constante afirmación de que "la honra es exclusivamente para Dios" y la reiterada exposición del número (que llegarían a decenas de miles) de personas beneficiadas, acaba haciendo una fuerte propaganda de lo que sería práctica fundamental del cristianismo: la ayuda al prójimo. En los tres meses de observación se constata hasta diez transmisiones dedicadas a divulgar cuánta ayuda había hecho: número de canastas básicas, número de familias alcanzadas, etc. Ellos mismos se admiran de la cantidad de personas que han recibido ayuda. El fenómeno parece una práctica "narcisa", se miran al espejo y se admiran: que buenos que somos. No conseguimos información del origen de los recursos económicos que cubrían esos costos. En algunos videos de distribución de bienes se constatan participación de personal del gobierno y de la policía, lo que lleva a suponer de algún tipo de colaboración con el Estado. Como ejemplo de este tipo están: la Iglesia Bíblica Emanuel, la Iglesia Camino de Vida, la Iglesia Bíblica de La Molina, la Alianza Cristiana y Misionera de Lince y la Comunidad Cristiana Agua Viva, también del distrito de Lince.

\section{C)El Evangelio no está en cuarentena: Dios contra el nuevo orden mundial}

En este tercer tipo incluimos a las iglesias que, en grados diferentes y motivaciones también diversas, ignoran la pandemia como un problema 
de salud. Algunas la consideran un castigo de Dios, oportunidad para evangelizar o como desafío al poder de Dios. Otras consideran que el virus no es real. Se trataría de una farsa inventada por el comunismo chino dentro de un malévolo plan denominado "nuevo orden mundial" o "globalismo". Esas características se encuentran tanto en iglesias de zonas populares (como Los Olivos y San Martín de Porres) como en iglesias de zonas de clase media y media baja (como Jesús Maria y Pueblo Libre). Ese sector del campo evangélico tiene en común una militancia contra la igualdad de género que es previa a la pandemia. En los sectores más populares que conforman este tipo se manifiesta un fuerte tono apocalíptico próximo al "pánico moral” (THOMPSON 1998 y GOODE \& BEN-YEHUDA 2003), en los sectores más acomodados se manifiesta un discurso políticoreligioso, con importante presencia en los medios de comunicación, que en el nivel nacional se reciente mucho por no poder abrir los templos. Las iglesias que cuentan con acceso privilegiado a radio y tv (como el Movimiento Misionero Mundial) y que llegan a sectores bajos y medios de la población, resuelven fácilmente el problema al pasar a hacer transmisiones por esos canales. También se encuentra en este tipo claros aspectos de un "protofascismo" 20 , confesadamente alineado con una soberanía del actual gobierno norteamericano de Donald Trump. Éstas representan el componente extremo de este tercer tipo. En la actual circunstancia es difícil dimensionar su impacto en los sectores evangélicos más vulnerables.

Los discursos de este tipo se expresan de maneras diversas, como las siguientes: "el virus es tribulación que Dios lo está permitiendo para darnos victoria", "Europa le dio las espaldas a Dios al aprobar el homosexualismo y el aborto y ahora Él nos está advirtiendo", "no hay que desanimarse porque al final Dios va a mostrar su verdadero propósito". En los sermones el virus sólo aparece como oportunidad para evangelizar: "El evangelio no está de cuarentena". En la práctica esa afirmación se expresa en campañas

20 Un "protofascismo", utilizado aqui en el sentido de primigenio, primario o principiante, pero también en el sentido de tener ya por lo menos algunas marcas de un modelo anteriormente consolidado, como el fascismo italiano. Umberto Eco utiliza la expresión "ur-fascismo" y entre las características incluye las siguientes dos (que se confirman para el caso que estudiamos): se manifiesta abiertamente contra el pluralismo expresando miedo a la diferencia y substituye la violência física por la agresividad retórica. Diferente del fascismo el nazismo no se queda en la violencia retórica porque cuenta con militantes organizados y milícias, también actuan bajo la protección de un líder salvador al que idolatram (ECO 2018). En nuestro caso el líder salvador es explícito: Donald Trump. 
presenciales de evangelización en "Asentamientos Humanos", violando la prohibición de recogimiento por la cuarentena. Son acciones organizadas y frecuentes a lo largo de los tres meses observados, con equipo de sonido, grupo de personas distribuyendo folletos en las casas. En sus redes reproducen mensajes del colectivo "Parejas reales" y de "Con mis hijos no te metas". En sus arriesgadas campañas en zonas populares (en los videos se ven claramente los cerros de Lima y la pobreza de las construcciones y vestimentas de la población convocada) utilizan con frecuencia testimonios de homosexuales "transformados por Dios". Un banner con la imagen de "cuando era mujer" está presente en la mayoría de los videos de esas campañas. El mensaje dirigido a gente pobre y simple llega a ser de chantaje: “o se arrepienten o serán destruidos", "la segunda venida de Cristo está cerca". Son frases utilizadas antes de entregar ropa y alimentos colocados en el suelo.

Como sería de esperar, en los sectores más pobres, el uso de las redes es más precario. Sermones con imagen congelada con transmisión sólo de video, uso de videos de cultos anteriores a la pandemia, películas reproducidas en la página de la iglesia, reunión de oración y testimonios de conversión de mujeres migrantes transmitidas en directo son parte de su repertorio más común. Al inicio de junio, se verifica frecuentes casos de muertes de fieles y de líderes. Por ejemplo, el 8 de junio el "Consejo Directivo Nacional" (de una iglesia pentecostal) comunica a los "Consiervos e Iglesia en General" que hay dos pastores enfermos. Uno internado en el Hospital Loaysa de Lima y otro "aislado en su casa en Trujillo". Una semana después se comunica el fallecimiento del primero. En ningún caso se menciona la causa de la muerte. Al mismo tiempo se destaca que "pasaron a la presencia de Dios cumpliendo fielmente su compromiso de predicar el Evangelio".

Cabe destacar dentro de este tercer tipo algunas prácticas que se aproximan peligrosamente a un protofascismo, como mencionamos anteriormente. Los mensajes televisivos del Movimiento Misionero Mundial y un conjunto diverso de "influencers" evangélicos actuando en las redes y los medios, son su más clara expresión. ${ }^{21}$ Dos casos destacados que observamos son líderes del movimiento "Con mis hijos no te metas", los mismos que antes

21 Para los próximos párrafos nos apoyamos en "posts" de los autores/as divulgadas en el "face" y en periódicos entre el mês de mayo y princípios de junio del 2020. Cf: https://www.facebook.com/crosas89 y https://www.facebook.com/profile. php?id=100001891208705, respectivamente. 
de la pandemia movilizaban buena parte del campo evangélico en acciones contra los derechos de minorías. Ambos reclaman recalcitrantemente por el cierre de los templos en lo que ven una persecución o un recorte del derecho a la libertad de expresión. A lo largo de los primeros tres meses de pandemia se observa que dedican buena parte de sus espacios en las redes y periódicos a divulgar las bondades de la administración Trump, inclusive a hacer propaganda electoral en favor del mismo y a defender a las clínicas privadas. En el mes de junio cuando el escándalo de las clínicas privadas obligó al Presidente a exigir la colaboración de las mismas, encontramos la siguiente reacción:

Medida populista y demagógica. Vizcarra es una especie de Rey Midas pero al revés, todo lo que toca lo oxida y lo convierte en obsoleto. Las clínicas privadas no fueron construidas con dinero público, sino privado, el sector privado puede atender a todos y el estado puede asumir las tarifas que planteen, se puede negociar un precio justo, pero expropiar y estatizar es algo descabellado e innecesario. Algunos con un complejo irremediable de súbditos aplauden estos excesos estatales, como siempre cayendo en la trampa idealista, mentes ingenuas que no aprenden de los fracasos de estas viejas y comprobadamente inútiles ideas. (Idem)

Una obsesión por el libre mercado es recurrente. Hasta donde sabemos tales "influencers" no son dueños de clínicas, pero no cabe duda que están al servicio de los ideales de las grandes empresas que no permiten ninguna interferencia en sus sagradas propiedades, ni en medio a la grave crisis sanitaria que cobra miles de vidas. Se puede inferir, sin exagerar, que ya se trata de campaña electoral (recuérdese que el 2021 habrá elecciones generales) y la CONFIEP necesita congresistas como estos. Que defiendan el estado mínimo. La población sufrida y mortalmente golpeada por el virus recibió con euforia, como sería de esperar, la noticia (esa sí populista) del Presidente de que las clínicas serían abiertas a todos. La configuración de las políticas de Estado, del actual presidente, siempre han sido benévolas con el sector privado, estando lejos de cualquier exigencia que afecte los intereses de las grandes empresas o la propiedad privada de los sectores más acomodados de la sociedad. El siguiente "post" corresponde al contexto de crisis deflagrada por la crueldad policiaca de los Estados Unidos que ocasionó la muerte por asfixia de George Floyd. El "post” es acompañado de una imagen con personas civiles armadas protegiendo los muros de sus casas: 
Esto sucede cuando la marcha deja la ciudad metropolitana, que se presta a los disturbios por estar vacía, y llega a la zona residencial donde un solo pie en el jardín de propiedad privada otorga el derecho de fusilar en los Estados Unidos. Tanto así que muchas casas colocan un letrero en su jardín que dice: Prohibido Traspasar. Casa Armada - se Disparará a Matar. Esto ha generado que el crimen de robo armado en casas sea muy bajo, algo que es común en Latinoamérica... Si se arma al pueblo no se le puede abusar...(Idem)

La Organización Mundial de la Salud (OMS) es también uno de sus blancos privilegiados y ven en la misma el espectro fantasmal del "Nuevo orden mundial". El siguiente "post" divulga el titular: "Ganador del nobel dice que la cuarentena mató más personas de las que salvó”:

Cuando los grandes científicos y ganadores de Nobel son ignorados y se cree todo de lo que la OMS dice, esa organización dirigida por burócratas que pretendía facilitar el asesinato de bebés inocentes en plena cuarentena prestándose para presionar a las naciones a no impedir estos servicios “esenciales". Honra a quien honra merece, no a quien se ha vaciado de toda legitimidad por sus propias acciones inhumanas y hoy espera credibilidad. (Idem)

Entre los meses de mayo y junio del 2020 se constata en el "face" de otra "influencer" un trabajo en redes hecho con esmerada dedicación. ${ }^{22}$ Sus baterías (porque son acusaciones fulminantes) se concentran contra la OMS y en elogios a decisiones de Trump. Citamos solamente dos ejemplos: en una reproduce una materia del Washington Times" cuyo titular es "Trump finalizes rule defining gender as a person's biological sex" ("Trump concluye normas que definen género como sexo biológico de una persona”). El "post" tiene el siguiente comentario: "Excelente Presidente Donald Trump, devolviendo la cordura moral a Norteamérica". También, para ella la OMS es una organización terrorista internacional, parte de "la élite globalista" que planea "la muerte de dos tercios de la población mundial". El COVID19 sería parte de ese plan $y$, diferente de lo que se sabe, para ella el virus no se contagia de persona a persona sino que habría sido diseminado intencionalmente en el planeta. A principios de junio, cuando la prensa mundial informaba que Trump había decidido cortar su apoyo financiero a la OMS, ella se pronuncia: "Presidente Trunp sabe lo que hace en bien no sólo de los Estados Unidos de Norteamérica sino de toda la humanidad". Un último ejemplo, en una de sus columnas en el periódico Expreso (de Lima) así se manifiesta:

22 https://www.facebook.com/profile.php?id=100001891208705. Múltiples accesos entre abril y mayo del 2020 . 
Religión y COVID 19 en el Perú del Bicentenario. 459 Laicidad de colaboración y reacciones evangélicas a la pandemia

Es sorprendente ver cómo gobiernos sometidos a la élite globalista que nos está imponiendo un siniestro gobierno mundial, en el momento crucial de ver morir a sus compatriotas por la pandemia planificada con que están exterminando a los pueblos selectivamente, han hecho a un lado las órdenes de los organismos internacionales, cuyos dictados habían venido obedeciendo a nivel político, económico, social y cultural, y han recurrido a una inspiradora toma de decisiones nacionalistas en resguardo a la integridad y la vida de los pueblos. Lamentable comprobar que en Perú no ha sucedido así. (Idem)

Para finalizar el análisis de este tercer tipo, destacamos algunos ejemplos de iglesias (además de los "influencers") que constituyen la mayoría del campo evangélico: diversas iglesias de las Asambleas de Dios, como la de Cayaltí, la Iglesia Evangélica Pentecostal Misionera de los Olivos y la Iglesia Apostólica y Profética Jesús la Luz del Mundo.

\section{Consideraciones finales}

El COVID 19 llegó al Perú al inicio del mes de marzo del 2020. La declaración, de parte del Estado, de emergencia sanitaria fue seguida casi de inmediato de la emergencia nacional, siendo el Perú el primer país de América Latina en decidirlo. Esa decisión parecía temprana y hasta exagerada. Las reacciones mayoritarias de las iglesias, ante el cierre de los templos, muestra que no se tenía real dimensión de los alcances de la pandemia. Se esperaba que realmente al cabo de los 15 días (iniciales) del estado de "emergencia nacional" las actividades religiosas volverían a la normalidad. Es difícil imaginar que el Estado, al inicio de la pandemia, no haya tenido la información científica de los alcances desastrosos del problema, pues ya se sabía de sus efectos en la China y su avance arrollador en los países de Europa. Al mismo tiempo, como abordado en la primera parte de este artículo, el Estado peruano tenía pleno conocimiento de la fragilidad en que se encontraba el sistema de salud pública antes de la pandemia. Tenía conciencia también de su genuflexión ante los intereses de las grandes empresas, en particular del monopolio en las productoras del oxígeno medicinal y de las redes de farmacias. La decisión temprana de emergencia nacional obedecía, entonces, más a una preocupación por saber que el sistema de salud pública no tenía condiciones de enfrentar la pandemia que a una planificación estratégica y planificada para reducir sus efectos.

De hecho, la búsqueda (temprana también y a lo largo de los tres meses estudiados) del apoyo de las iglesias expresa también, como abordado en la 
segunda parte de este texto, la fragilidad de respuesta del Estado en términos de recursos científicos y técnicos. La valoración y reconocimiento del papel de las iglesias (totalmente legítimo) debe entenderse en ese contexto. Los tres eventos que expresan esa relación de colaboración Iglesias - Estado deben, evidentemente, haber tenido importante impacto emocional, psicológico y espiritual, por causa de su amplia divulgación en los más diversos medios. Los efectos prácticos en términos de asistencia social, de distribución de bienes básicos de sobrevivencia y de salud, son muy difíciles de medir. Debemos subrayar, sin embargo, que no se encuentra evidencia y ni sería de esperar que la participación de las iglesias haya tenido algún impacto en la respuesta propiamente técnica y científica a la pandemia. La cuestión es muy importante porque pone en evidencia el aspecto secular, desencantado, no religioso del sistema de salud. La pandemia pone al desnudo la fragilidad de la sanidad divina, de la cura milagrosa y de la protección divina, elementos importantes de la piedad evangélica y del sistema religioso, especialmente pentecostal.

Específicamente en el campo religioso evangélico, las respuestas a la pandemia se muestran tan diversas como la propia diversidad de tradiciones evangélicas. Para esquivar esa dificultad ensayamos, en la tercera parte de este artículo, una tipología de reacciones ante el avance del virus. Los "tipos ideales" (Weber) propuestos permiten una organización mínima de las múltiples respuestas. Se detectan claras tendencias que las agrupamos en tres tipos que no corresponden stricto sensu a las condiciones sociales y económicas de la sociedad peruana, por lo demás bastante desigual y con alta concentración de renta y riqueza. De todas maneras, las diferencias sociales y económicas son un factor importante que influye fuertemente en la práctica religiosa durante la pandemia y en la forma de respuesta a ella. Otros factores son también muy importantes, por ejemplo, la mayor o menor comprensión que el grupo religioso tiene de las relaciones de poder en la sociedad. Quien entiende mejor la fragilidad del Estado frente al poder del sector privado y la precariedad de todo el sistema de salud, consigue entender también la necesidad de organizar a la comunidad religiosa para una sobrevivencia a mediano o largo plazo. Quien no lo entiende se limita a la oración de consuelo e incluso se insiste en la cura divina o en la negación de la propia pandemia. Debemos destacar, finalmente, que los límites de este trabajo corresponden a las dificultades de acceso a información impuestas por el confinamiento. El trabajo etnográfico remoto, o virtual, es un nuevo desafío para los estudios sociales de los fenómenos religiosos. Por el momento, 
Religión y COVID 19 en el Perú del Bicentenario. 461

Laicidad de colaboración y reacciones evangélicas a la pandemia

para el caso estudiado, se muestra una rica fuente de información con sus limitaciones evidentes, por ejemplo, el hecho de que muchas iglesias no se hacen presentes en ambiente digital.

\section{Bibliografía}

BARRERA RIVERA, Paulo. “Don't you mess with my children. Conservative Inter-religous Cooperation in Peru in the XXI Century" in: IJLR, 2017. https://doi.org/10.1007/S41603017-0030-5

BAUBÉROT, Jean et MILOT, Micheline, Laïcités sans frontières. Paris, Seuil, 2011

BOURRICAUD, François. Poder y sociedad en el Perú, Lima, IEP, 1967

DEFENSORÍA DEL PUEBLO. Estado de emergencia sanitária: el problema de la informalidade laboral en una economia confinada". Lima, Serie Informes Especiales $\mathrm{N}^{\circ}$ 02-2020-DP Disponible en: https://www.defensoria.gob.pe/wp-content/uploads/2020/04/ Serie-de-Informes-Especiales-N\%C2\%B0-02-2020-DP-Problema-de-la-informalidad-laboralen-una-economia-confinada.pdf

DRINOT, Paulo. La seducción de la clase obrera. Trabajadores, raza y la formación del Estado peruano. Lima, IEP, 2016

ECO, Umberto. O Fascismo eterno. Rio de Janeiro, Record, 2018.

ENARES, Encuesta Nacional sobre relaciones sociales. Lima, NEI, 2019. Disponible en: https://www.inei.gob.pe/media/MenuRecursivo/boletines/presentacion_enares_2019. pdf?fbclid=IwAR3equCv_oD20TSDEyI9eWQI0j8wPCKLN8fIgl3vkA2k7aXIT0OuuPytllA

FLORES, Alberto. Buscando un Inca. Identidad y utopía en los andes. Lima, Horizonte, 1994

FLORES, Alberto. La tradición autoritaria. Violencia y democracia en el Perú. Lima, APRODHE, SUR, 1999

GARCÍA, Patricia (Dir). Salud pública en el Perú. Aproximaciones y nuevos horizontes. Lima, MINSA, UCH, 2014

GOODE, Erich \& BEN-YEHUDA, Nachman. Moral Panics. The Social Construction of Deviance. Malden, Blackwell Publishing, 2003

KOWARICK, Lúcio, Viver em risco. Sobre a vulnerabilidade socioeconómica e civil. São Paulo, Editora 34, 2009

LECAROS, Véronique, La conversión al evangelismo. Lima, PUC Perú, 2013 (el original en francés, de 2013, tiene el subtítulo "Le cas de Pérou", lamentablemente retirado de la versión en español).

LECAROS, Véronique. Fe cristiana y secularización en el Perú de hoy. Lima, Universidad Antonio Ruiz de Montoya, 2017 
LÓPEZ, Dario y ARROYO, Víctor. Tejiendo un nuevo rostro público. Evangélicos, sociedad y política en el Perú contemporáneo. Lima, Puma, 2008

LÓPEZ, Dario. Los Evangélicos y los Derechos Humanos. La experiencia social del Concilio Nacional Evangélico del Perú 1980-1992. Lima, CEMAA, 1998

LÓPEZ, Darío. La Seducción del poder. Los evangélicos y la política en el Perú de los noventa, Lima, PUMA, 2014

LOSIO, Jorge y BARRIGA, Eduardo (Eds). La salud pública en el Perú del siglo XX. Paradigmas. Discursos y política. Lima, Instituto Riva Aguero - PUCP, 2017

MALLIMACI, Fortunato. El mito de la Argentina laica. Catolicismo, política y Estados. Buenos Aires, Capital Intelectual, 2015

MANRIQUE, Nelson. Una alucinación consensual. Redes sociales, cultura y socialización en internet. Lima, PUC, 2016

MILOT, Micheline. La Laïcité. Montrel, Novalis, 2008

MOTTA, Angélica. La biología del odio. Retóricas fundamentalistas y otras violencias de género. Lima, La Siniestra, 2019.

THOMPSON, Kenneth. Moral Panics. London, Routledge, 1998

WEBER, Max. Economía y Sociedad. México, FCE, 1984

WEBER, Max. Sobre a teoria das ciências sociais. São Paulo, Morães, 1967

Sites consultados:

https://www.defensoria.gob.pe/areas_tematicas/acceso-a-la-salud/

https://ojo-publico.com/1842/dos-companias-globales-dominan-negocio-del-oxigeno-en-peru https://larepublica.pe/

https:// noticias-pe.laiglesiadejesucristo.org/articulo/presidente-vizcarra-presentar $\% \mathrm{C} 3 \% \mathrm{~A} 1$ video-de-oraci $\% \mathrm{C} 3 \% \mathrm{~B} 3 \mathrm{n}$-interreligiosa

https://www.arzobispadodelima.org/2020/05/14/peru-lideres-religiosos-unidos-salud/

Submetido em:19-7-2020

Aceito em: 25-7-2020 